\title{
EVALUASI PELAKSANAAN TEACHING FACTORY SMK DI SURAKARTA
}

\author{
Nuryake Fajaryati \\ Jurusan Pendidikan Teknik Elektronika Fakultas Teknik UNY \\ yaqe.fy@gmail.com
}

\begin{abstract}
Abstrak: Evaluasi Pelaksanaan Teaching Factory SMK di Surakarta. Evaluasi pelaksanaan teaching factory SMK di Surakarta bertujuan untuk mengetahui bagaimana proses pelaksanaan teaching factory SMK di Surakarta. Penelitian ini merupakan penelitian deskriptif dengan pendekatan evaluasi model formatif-sumatif oleh Scriven yang menekankan pada evaluasi formatif. Populasi penelitian adalah semua SMK di Surakarta yang menjalankan teaching factory berjumlah 9 sekolah dan respondennya adalah 81 guru pengampu kompetensi keahlian yang menjalankan teaching factory di sekolah tersebut. Hasil penelitian menunjukkan bahwa pelaksanaan teaching factory SMK di Surakarta ditinjau dari kegiatan pembelajaran dinyatakan sangat baik (17,28\%) oleh 14 guru, baik (39,51\%) oleh 32 guru, tidak baik (25,93\%) oleh 21 guru, dan sangat tidak baik (17,28\%) oleh 14 guru. Sedangkan hasil pelaksanaan teaching factory SMK di Surakarta ditinjau dari proses produksi dinyatakan sangat baik $(14,81 \%)$ oleh 12 guru, baik (27,16\%) oleh 22 guru, tidak baik (44,44\%) oleh 36 guru, dan sangat tidak baik $(13,58 \%)$ oleh 11 guru.
\end{abstract}

Kata kunci: teaching factory, kegiatan pembelajaran, proses produksi

\section{EVALUATION OF SMK TEACHING FACTORY IN SURAKARTA}

\begin{abstract}
Evaluation Of SMK Teaching Factory in Surakarta. An evaluation of the teaching factory implementation in vocational high schools (VHSs) in Surakarta aims to find out he teaching factory implementation process in VHSs in Surakarta. This was a descriptive study with the formative-sumative evaluation model by Scriven emphasizing on the formative evaluation. The population comprised all 9 VHSs in Surakarta carrying out the teaching factory. The respondents were 81 teachers involved in the teaching factory. The results of the evaluation show that the teaching factory in VHSs in Surakarta for the learning activity component is very good (17.28\%, 14 respondents), good (39.51\%, 32 respondents), poor $(25.93 \%, 21$ respondents), and very poor $(17.28 \%, 14$ respondents), and for the production proccess component it is very good $(14.81 \%, 12$ respondents), good $(27.16 \%, 22$ respondents), poor (44.44\%, 36 respondents), and very poor (13.58\%, 11 respondents).
\end{abstract}

Keywords: teaching factory, learning, production proccess 


\section{PENDAHULUAN}

Ilmu pengetahuan dan teknologi berkembang dengan begitu pesat tetapi perkembangan ini tidak diimbangi dengan sumber daya manusia yang memadai. Di era pasar yang sedang berkembang, dunia industri mengupayakan nilai tambah terhadap produksinya dengan memanfaatkan teknologiteknologi tinggi. Setiap perusahaan ingin meningkatkan produktivitasnya sehingga target yang menjadi tujuan perusahaan tersebut dapat tercapai. Untuk memanfaatkan teknologi tinggi dan meningkatkan produktivitas ini maka dunia industri membutuhkan sumber daya manusia yang berkualitas.

Munculnya berbagai permasalahan tersebut kemudian mendorong pendidikan kejuruan berupaya untuk menghasilkan SDM yang berkompeten di bidangnya, mempersiapkan peserta didiknya dalam memasuki dunia kerja ataupun memasuki jenjang pendidikan yang lebih tinggi.

Merujuk dari permasalahan tersebut, Kota Surakarta sebagai Kota Vokasi mempunyai banyak program untuk meningkatkan kualitas mutu pendidikan, salah satunya adalah program teaching factory. Menurut Data Pokok SMK Direktorat Pembinaan Sekolah Menengah Kejuruan, terdapat 48 SMK di kota Surakarta, yaitu 9 SMK Negeri dan 39 SMK Swasta. Berdasarkan data pokok dan hasil survei yang telah dilakukan, ada beberapa SMK di Surakarta yang menjalankan model pembelajaran teaching factory, yaitu SMK Warga, SMK Marsudirini Marganingsih, SMK Batik 1, SMK Katolik St. Mikael, SMK Sahid, SMK Tunas Pembangunan 2, SMK Negeri 1, SMK Negeri 2, SMK Negeri 5, dan SMK Negeri 6.
Pelaksanaan teaching factory tidak terlepas dari berbagai masalah yang dihadapi. Oleh karena itu upaya untuk mengatasi berbagai permasalahan dan upaya pengembangan mutu SMK yang merupakan bagian dari program kota vokasi perlu dilakukan suatu evaluasi pelaksanaan teaching factory SMK di Surakarta. Melalui evaluasi ini diharapkan dapat diketahui bagaimana proses pelaksanaan dalam kegiatan pembelajarannya, hambatan dan kendala apa yang dihadapi selama proses pelaksanaan, dan hal-hal apa saja yang harus diperbaiki dan ditingkatkan dalam proses pelaksanaan teaching factory.

\section{Pembelajaran Berbasis Kompetensi}

Menurut Direktorat PSMK (2012: 4-5), dalam proses pembelajaran di lingkup SMK, pelaksanaan teaching factory diterapkan dalam berbagai bidang studi keahlian, yaitu: a) Agribisnis dan Agroteknologi, b) Bisnis dan Manajemen; c) Teknologi dan Rekayasa; d) Teknologi Informasi Komunikasi (TIK); e)Seni, Kerajinan dan Pariwisata.

Teaching factory dapat juga dikatakan sebagai gabungan dari pendekatan pembelajaran berbasis kompetensi dan pembelajaran berbasis produksi. Artinya bahwa suatu proses keahlian atau keterampilan dirancang dan dilaksanakan berdasarkan prosedur dan standar bekerja yang sesungguhnya untuk menghasilkan produk yang sesuai dengan tuntutan pasar/ konsumen. Produk yang dihasilkan dapat berupa barang maupun jasa.

Menurut Graeme Dobson (2003: 8) pembelajaran berbasis kompetensi merupakan suatu pembelajaran yang bertujuan untuk membantu peserta didik memperoleh 
keterampilan dan pengetahuan sehingga mereka mampu melakukan tugas sesuai dengan standar yang telah ditetapkan.

E. Mulyasa (2006: 39) mengartikan bahwa pembelajaran berbasis kompetensi merupakan suatu konsep pembelajaran yang menekankan pada pengembangan kemampuan melakukan (kompetensi) tugas-tugas dengan standar performansi tertentu sehingga hasilnya dapat dirasakan oleh peserta didik berupa penguasaan terhadap seperangkat kompetensi tertentu. Pembelajaran berbasis kompetensi diarahkan untuk mengembangkan pengetahuan, pemahaman, kemampuan, nilai, sikap, dan minat peserta didik agar dapat melakukan sesuatu dalam bentuk kemahiran, ketetapan, dan keberhasilan dengan penuh tanggung jawab.

Depdiknas dalam Mulyasa (2006: 42) mengemukakan bahwa kurikulum berbasis kompetensi memiliki beberapa karakteristik. Karakteristik tersebut di antaranya yaitu: (1) menekankan pada ketercapaian kompetensi siswa baik secara individual maupun klasikal; (2) berorientasi pada hasil belajar (learning outcomes) dan keberagaman; (3) penyampaian pembelajaran menggunakan metode yang bervariasi; (4) sumber belajar bukan hanya guru melainkan juga sumber belajar lain yang memenuhi unsur edukatif; (5) penilaian ditekankan pada proses dan hasil belajar dalam upaya penguasaan atau pencapaian suatu kompetensi.

Menurut Herminarto Sofyan (2008: 10), pembelajaran berbasis kompetensi menekankan pada pencapaian kompetensi peserta didik. Kompetensi peserta didik dapat dicapai melalui pembelajaran: (1) berpusat pada peserta didik (student active learning); (2) belajar dengan melakukan (learning by doing); mengembangkan kecerdasan intelektual, emosional, spiritual, dan sosial; (4) belajar mandiri dan belajar bekerjasama.

\section{Pembelajaran Berbasis Produksi}

Seperti yang telah diungkap di atas, teaching factory merupakan perpaduan dari pembelajaran berbasis produksi dan kompetensi. Harianton dan Saefudin (2010: 75) menyatakan bahwa pada pembelajaran berbasis produksi, siswa terlibat langsung dalam proses produksi. Sehingga kompetensi yang dimiliki oleh siswa banyak dipengaruhi dari kasus produksi yang mereka hadapi. Kapasitas produksi pada pendekatan ini menjadi perhatian utama dan pemilihan kasus menjadi kunci utama keberhasilan pelaksanaan dari pembelajaran berbasis produksi.

Menurut Production Work Handbook oleh Public Schools of North Carolina (1997: 1-2), production work dalam kegiatan pendidikan mempunyai beberapa tujuan, yaitu: (1) mempersiapkan individu menjadi pekerja; (2) mempersiapkan individu untuk melanjutkan ke pendidikan yang lebih tinggi; (3) membantu siswa untuk memilih bidang kerja yang sesuai dengan kemampuannya; (4) menunjukkan bahwa 'learning by doing' sangat penting bagi efektivitas pendidikan; (5) mendefinisikan keterampilan yang dibutuhkan dalam dunia kerja; (6) memperluas kesempatan rekruitmen bagi siswa; (7) memberi kesempatan kepada guru untuk memperluas wawasan instruksional sehingga bisa membantu siswa dalam mempersiapkan diri menjadi tenaga kerja, bagaimana menjalin kerjasama dalam dunia kerja yang aktual, dll; (8) memberikan 
kesempatan kepada siswa untuk melatih keterampilannya sehingga dapat mebuat keputusan tentang karir yang akan dipilihnya; (9) memberi kesempatan kepada guru untuk membangun 'jembatan instruksional' antara kelas dengan dunia kerja; (10) membuat program pembelajaran lebih menarik dan memotivasi siswa untuk belajar.

\section{Teaching Factory}

Lamancusa, Zayas, Soyster, Morel, dan Jorgensen (2008: 7) menyatakan bahwa konsep teaching factory ditemukan karena tiga faktor yaitu: (1) pembelajaran yang biasa saja tidak cukup; (2) keuntungan peserta didik diperoleh dari pengalaman praktik secara langsung; dan (3) pengalaman, pembelajaran berbasis team yang melibatkan siswa, staf pengajar dan partisipasi industri memperkaya proses pendidikan dan memberikan manfaat yang nyata bagi semua pihak.

\section{Kemudian menurut Lamancusa,} Jorgensen, Zayas-Castro, Ratner (1995: 5), prinsip dasar tearning factory merupakan pengintegrasian pengalaman dunia kerja ke dalam kurikulum sekolah. Semua peralatan dan bahan serta pelaku pendidikan disusun dan dirancang untuk melakukan proses produksi dengan tujuan untuk menghasilkan produk (barang ataupun jasa).

Moerwismadhi (2009: 2) mengungkapkan bahwa dalam teaching factory, sekolah melaksanakan kegiatan produksi atau layanan jasa yang merupakan bagian dari proses belajar mengajar. Dengan demikian sekolah diharuskan memiliki sebuah pabrik, workshop atau unit usaha lain untuk kegiatan pembelajaran.
Kemudian Sudiyanto (2011: 5) dalam penelitiannya menyatakan bahwa, teaching factory merupakan suatu kegiatan pembelajaran dengan melakukan kegiatan produksi baik berupa barang atau jasa di dalam lingkungan pendidikan sekolah oleh siswa. Barang atau jasa yang dihasilkan oleh siswa memiliki kualitas sehingga layak jual dan diterima oleh masyarakat atau konsumen. Hasil keuntungan yang didapatkan diharapkan dapat menambah sumber pendapatan sekolah yang berguna untuk keberlangsungan kegiatan pendidikan. Teaching factory menghadirkan dunia industri/kerja yang sesungguhnya dalam lingkungan sekolah untuk menyiapkan lulusan yang siap kerja.

Hadlock, Wells, Hall, Clifford, Winowich, dan Burns (2008: 14) mengungkapkan bahwa teaching factory mempunyai tujuan yaitu menyadarkan bahwa mengajar siswa seharusnya lebih dari sekedar apa yang terdapat dalam buku. Siswa tidak hanya mempraktikkan soft skill dalam pembelajaran, belajar untuk bekerja secara tim, melatih kemampuan komunikasi interpersonal, tetapi juga mendapatkan pengalaman secara langsung dan latihan bekerja untuk memasuki dunia kerja nantinya.

Dari uraian di atas diperoleh kesimpulan bahwa teaching factory merupakan suatu gabungan dari pendekatan pembelajaran berbasis kompetensi dan pembelajaran berbasis produksi dimana proses belajar mengajar dilakukan seperti di dunia kerja yang sesungguhnya dengan mengadakan kegiatan produksi atau layanan jasa di lingkungan sekolah. Barang atau jasa yang dihasilkan memiliki kualitas sehingga layak jual dan dapat diterima masyarakat atau konsumen. Adapun 
beberapa indikator pelaksanaan teaching factory di SMK adalah sebagai berikut: 1. Kegiatan pembelajaran, meliputi: a) proses pembelajaran keahlian atau keterampilan yang dirancang dan dilaksanakan berdasarkan prosedur dan standar bekerja yang sesungguhnya (real job); b) setting pembelajaran dibuat semirip mungkin dengan situasi kerja nyata, yaitu melalui unit produksi, bisnis center, atau unit usaha lain; c) berorientasi problem solving; d) berpusat pada peserta didik (student active learning), belajar mandiri (individual learning) dan bekerjasama; e) belajar dengan melakukan (learning by doing); f) menekankan pada ketercapaian kompetensi atau hasil belajar (learning outcomes) siswa secara individual dan klasikal sesuai standar kerja tertentu; g) mengembangkan soft skill pada siswa, yang meliputi kecerdasan intelektual, emosional, spiritual, dan sosial; mampu menanggapi penyimpangan dan kerusakan; bertanggung jawab dalam lingkungan pekerjaannya; mampu berkomunikasi dengan baik; kemampuan membangun komitmen; dan kreatifitas; h) melatih siswa untuk belajar terus menerus sehingga mudah beradaptasi dengan pengetahuan baru; i) Melaksanakan sosialisasi kepada tenaga pendidik dan kependidikan, siswa, orang tua siswa dan mitra SMK tentang pendekatan dan strategi (pola) pembelajaran teaching factory; j) melaksanakan pengembangan pola pembelajaran berbasis bisnis yang berkelanjutan; k) Mengorganisasikan dan menyiapkan siswa yang terlibat; 1) memberikan pembimbingan dan konsultasi kepada siswa dalam pelaksanaan kegiatan pembelajaran teaching factory; m) melaksanakan evaluasi dan perbaikan hasil pembelajaran teaching factory secara bertahap dan terus menerus; 2. Proses produksi, yang terdiri dari a) perencanaan yang meliputi: (1) Membuat program kerja pelaksanaan pengadaan barang yang berisi jadwal dan urutan pekerjaan; (2) pembuatan rencana kebutuhan barang/bahan dan peralatan penunjang dengan memperhatikan standar kualitas yang berlaku; (3) rencana survei harga barang/bahan; (4) menyediakan barang/bahan yang diperlukan bagi pelaksanaan teaching factory; (5) pemeriksaan bahan atau komponen yang akan dirakit/ pengecekan barang yang akan dijual; (6) pembuatan rekapitulasi bahan baku yang dibeli dari toko/pemasok; b) produksi, meliputi: (1) adanya desain produk sampai produk selesai (menghasilkan produk); (2) menyediakan pelayanan jasa; (3) menyediakan barang kebutuhan konsumen; (4) quality control; 3) Penjualan/pemasaran, meliputi: (1) Melakukan riset pasar; (2) menentukan strategi pemasaran yang sesuai; (3) membuat dan mengembangkan jaringan pasar dan distribusi; (4) melakukan promosi dan pencitraan produk/jasa; (5) Mengadakan hubungan/kontrak dengan relasi; 4) purna jual/ perbaikan, meliputi pemberian service jika terjadi kerusakan; 5) partnership, yaitu danya kerjasama dengan pemerintah, dunia kerja, masyarakat, dan SMK lain.

\section{Evaluasi}

Dalam suatu proses pembelajaran komponen yang turut menentukan keberhasilan suatu proses adalah evaluasi. Melalui evaluasi akan diketahui sejauh mana pelaksanaan pembelajaran, tujuan pendidikan, dan suatu program pendidikan dapat dicapai sesuai dengan tujuan yang diinginkan. 
Suharsimi Arikunto (2009: 2), menyatakan bahwa evaluasi merupakan suatu kegiatan untuk mengumpulkan informasi tentang bekerjanya sesuatu, yang selanjutnya informasi tersebut digunakan untuk menentukan alternatif yang tepat dalam mengambil sebuah keputusan.

Selain itu Rogers (2005: 2) mengungkapkan bahwa evaluasi merupakan suatu proses pengumpulan dan analisis informasi untuk membentuk suatu penilaian berdasarkan bukti yang kuat. Penilaian tersebut berkaitan tentang sejauhmana suatu target tercapai dan penilaian tersebut dapat membantu dalam pengambilan keputusan.

Dari berbagai pendapat yang telah diuraikan di atas, dapat disimpulkan bahwa evaluasi merupakan suatu kegiatan mengumpulkan informasi tentang suatu program yang mempunyai tujuan untuk mengetahui sampai sejauh mana pelaksanaan suatu program berjalan dan sampai sejauh mana tujuan program tersebut dapat tercapai. Selain itu evaluasi berguna untuk membantu menunjukkan kinerja apa saja yang perlu ditingkatkan, diperbaiki, ataupun dipertahankan dalam suatu program berdasarkan bukti yang diperoleh serta berguna untuk mengetahui berapa besar nilai dari kinerja penyelenggara program.

Kaufman dan Thomas dalam Suharsimi Arikunto (2009: 40-41) membedakan model evaluasi menjadi delapan, yaitu: (1) Goal Oriented Evaluation Model, dikembangkan oleh Tyler; (2) Goal Free Evaluation Model, dikembangkan oleh Scriven; (3) Formatif Summatif Evaluation Model, dikembangkan oleh Michael Scriven; (4) Countenance Evaluation Model, dikembangkan oleh Stake;
Responsive Evaluation Model, dikembangkan oleh Stake; (6) CSE-UCLA Evaluation Model, menekankan pada "kapan" evaluasi dilakukan; (7) CIPP Evaluation Model, dikembangkan oleh Stufflebeam; dan (8) Discrepancy Model, dikembangkan oleh Provus.

Model evaluasi yang tepat untuk program pemrosesan yaitu model goal oriented evaluation, model goal free evaluaion, model formative-sumative evaluation, deskripsi pertimbangan, model evaluasi CSE-UCLA, model evaluasi CIPP, model evaluasi kesenjangan (Suharsimi Arikunto, 2009: 52-55).

Dari berbagai macam model evaluasi seperti yang telah disebutkan di atas, salah satu model evaluasi yang tepat untuk program pemrosesan adalah model evaluasi formatifsumatif oleh Michael Scriven. Evaluasi formatif dilakukan selama program berlangsung, sedangkan evaluasi sumatif dilakukan sesudah program berakhir atau pada pada akhir penghujung program (Suharsimi Arikunto, 2009: 53-54).

Pada evaluasi pelaksanaan teaching factory SMK di Surakarta digunakan tipe evaluasi formatif oleh Scriven. Alasan pemilihan model evaluasi formatif karena program pembelajaran teaching factory SMK di Surakarta masih berlangsung dan belum berakhir. Selain itu pemilihan evaluasi formatif penting untuk dilakukan karena berdasarkan tujuan dan kegunaannya penelitian ini bertujuan untuk: 1) mengetahui bagaimana proses pelaksanaan teaching factory SMK di Surakarta; 2) mengetahui apa saja hambatan-hambatan yang terdapat dalam pelaksanaan teaching factory SMK di Surakarta; 3) mengetahui apa saja hal-hal yang harus diperbaiki dan 
ditingkatkan dalam proses pelaksanaan teaching factory SMK di Surakarta.

\section{METODE}

Jenis penelitian dikategorikan sebagai penelitian deskriptif dengan menggunakan pendekatan evaluasi. Pendekatan evaluasi yang digunakan adalah model evaluasi formatifsumatif oleh Scriven yang menekankan pada evaluasi formatif, yaitu evaluasi yang dilaksanakan selama program pelaksanaan teaching factory SMK di Surakarta tersebut berlangsung. Melalui evaluasi formatif tersebut dapat diketahui bagaimana pelaksanaan teaching factory, apa saja hambatan-hambatan yang muncul dalam pelaksanaan kegiatan, dan mengetahui hal-hal apa saja yang harus diperbaiki dan ditingkatkan dalam pelaksanaan teaching factory.

Pada penelitian ini yang menjadi populasi penelitian adalah 4 SMK Negeri dan 5 SMK Swasta di Surakarta yang menjalankan teaching factory, yaitu SMK Negeri 1, SMK Negeri 2, SMK Negeri 5, SMK Negeri 6, SMK Warga, SMK Tunas Pembangunan 2, SMK Batik 1, SMK Sahid, dan SMK Marsudirini Marganingsih. Sedangkan sampel yang digunakan adalah total dari jumlah populasi tersebut (sampel total). Responden dalam penelitian ini adalah guru-guru yang mengampu kompetensi keahlian yang melaksanakan teaching factory pada SMK tersebut di atas, yaitu 81 orang guru. Pemilihan responden tersebut dengan menggunakan teknik purposive sampling.

Variabel dalam penelitian ini adalah kegiatan pembelajaran dan proses produksi dalam teaching factory SMK di Surakarta.
Teknik Pengumpulan data dalam penelitian ini adalah dengan menggunakan metode angket dengan menggunakan model skala Likert sebagai data primer dan pertanyaan terbuka sebagai data pendukung. Isi instrumen (angket) yang telah dibuat kemudian divalidasi oleh judgment expert. Setelah divalidasi kemudian dilakukan uji coba terhadap angket tersebut.

Teknik analisis data dalam penelitian ini menggunakan teknik analisis deskriptif kuantitatif, yaitu dengan mendiskripsikan dan memaknai data dari variabel yang dievaluasi. Data yang diperoleh dari hasil penelitian dikumpulkan dan dianalisis berdasarkan ukuran tedensi sentral dan ukuran penyebaran data. Selain itu data dianalisis dengan menggunakan statistik deskriptif melalui bantuan program komputer statistic SPSS 17 for window untuk mendapatkan harga mean $(\mathrm{Me})$, median $(\mathrm{Md})$, skor maksimum, skor minimum, dan simpangan baku (SD). Data yang telah diolah tersebut kemudian dianalisis dan dideskripsikan dengan tujuan untuk memperoleh jawaban tentang halhal yang ingin diungkapkan sesuai dengan tujuan penelitian.

Instrumen/angket dalam penelitian ini menggunakan model skala Likert yang menggunakan empat alternatif jawaban, sehingga skor maksimum ideal diperoleh apabila semua butir pada komponen tersebut mendapat skor 4 atau skor maksimum pada alternatif jawaban dan skor minimum ideal diperoleh apabila semua butir pada komponen tersebut mendapat skor 1 atau skor minimum pada semua alternatif jawaban. Keseluruhan skor yang diperoleh disubstitusikan ke dalam tingkat kecenderungan yang dipakai sebagai kriteria dalam evaluasi. 
Menurut Djemari Mardapi (2008: 122123), penafsiran hasil pengukuran berdasarkan patokan kategori hasil pengukuran dengan menggunakan skala Likert dapat ditunjukkan pada tabel berikut, yaitu:

Tabel 1. Kriteria evaluasi untuk kegiatan pembelajaran dan proses produksi

\begin{tabular}{ccc}
\hline No. & \multicolumn{1}{c}{ Skor } & Kategori \\
\hline 1 & $\mathrm{X} \geq \overline{\mathrm{X}}+1 . \mathrm{SBx}$ & Sangat Baik \\
2 & $\bar{X}+1$. SBx $>\mathrm{X} \geq \overline{\mathrm{X}}$ & Baik \\
3 & $\bar{X}>\mathrm{X} \geq \overline{\mathrm{X}}-1 . \mathrm{SBx}$ & Tidak Baik \\
4 & $\mathrm{X}<\overline{\mathrm{X}}-1 . \mathrm{SBx}$ & Sangat Tidak Baik \\
\hline
\end{tabular}

Keterangan Tabel:

$\mathrm{X}$ : rerata skor keseluruhan

SBx : simpangan baku skor keseluruhan

$\mathrm{X} \quad$ : skor yang dicapai

Berdasarkan rumus di atas, maka diperoleh standar skor kategori kecenderungan untuk kegiatan pembelajaran dan proses produksi, yaitu kategori sangat baik, baik, tidak baik, sangat tidak baik.

\section{HASIL PENELITIAN DAN PEMBAHASAN}

Proses Pelaksanaan teaching factory SMK di Surakarta

\section{Kegiatan Pembelajaran}

Berdasarkan hasil penelitian, dapat diketahui bahwa kecenderungan guru dalam menilai pelaksanaan teaching factory SMK di Surakarta adalah sebagai berikut, yaitu guru yang menilai bahwa kegiatan pembelajaran berjalan dengan sangat baik berjumlah 14 orang dengan persentase $17,28 \%$, baik berjumlah 32 orang dengan persentase $39,51 \%$, tidak baik berjumlah 21 orang dengan persentase $25,93 \%$, sangat tidak baik berjumlah 14 orang dengan persentase $17,28 \%$.

Hasil kecenderungan tersebut menunjukkan bahwa pelaksanaan teaching factory SMK di Surakarta dari segi kegiatan pembelajaran telah berjalan dengan baik. Kegiatan pembelajaran dapat terlaksana dengan baik karena proses pembelajaran praktik dilakukan berdasarkan prosedur kerja yang sesungguhnya (real job), baik itu dalam hal produksi barang maupun jasa. Proses belajar mengajar dilakukan dengan beriontasi problem solving, yaitu dengan cara guru melatih siswa dalam menyelesaikan masalah yang muncul dalam proses produksi. Kegiatan pembelajaran yang berlangsung berpusat pada peserta didik (student active learning). Saat ini bukan guru yang menjadi pusat perhatian siswa (teacher centered) melainkan berpusat pada siswa. Guru melatih siswa untuk belajar mandiri (individual learning) dan mampu untuk bekerjasama.

Selain itu kegiatan belajar dilakukan dengan cara learning by doing, yaitu siswa tidak hanya dilimpahi dengan pemberian materi secara teori tetapi juga melalui praktik secara 
langsung. Pembelajaran difokuskan pada ketercapaian kompetensi atau hasil belajar (learning outcomes) siswa. Siswa tidak hanya menguasai materi secara teori melainkan juga dapat menguasai materi secara praktik, karena hal inilah yang nantinya dibutuhkan saat terjun ke dunia kerja sesungguhnya.

Dalam dunia kerja, tidak hanya membutuhkan hard skill semata, melainkan juga sangat memerlukan adanya soft skill. Kegiatan pembelajaran pada pelaksaan teaching factory termasuk dalam kategori baik karena pada proses belajar mengajar, guru mengembangkan soft skill pada siswa, yang meliputi kecerdasan intelektual, emosional, spiritual, dan sosial. Siswa diajarkan untuk mampu menanggapi penyimpangan dan kerusakan, bertanggung jawab dalam lingkungan pekerjaannya, mampu berkomunikasi dengan baik, kemampuan membangun komitmen, dan kreativitas. Selain itu siswa dilatih untuk belajar terus menerus sehingga mudah beradaptasi dengan pengetahuan baru dan teknologi yang semakin cepat berkembang.

Pelaksanaan teaching factory dapat berjalan dengan baik karena terdapat sosialisasi yang baik tentang adanya pendekatan dan strategi (pola) pembelajaran teaching factory kepada tenaga pendidik dan kependidikan, siswa, orang tua siswa dan mitra SMK sehingga dapat terjalin kerjasama yang baik dan menjadi sepaham dalam mencapai tujuan. Akan tetapi dalam implementasinya masih terdapat hambatan dalam melakukan sosialisasi tersebut. Selain itu sekolah juga melaksanakan pengembangan pola pembelajaran berbasis bisnis yang berkelanjutan dan guru menanamkan jiwa berwirausaha kepada peserta didik.
Kegiatan pembelajaran dalam pelaksanaan teaching factory dapat berjalan dengan baik karena guru menerapkan pembelajaran bisnis yang berkelanjutan. Guru menanamkan jiwa berwirausaha pada ke dalam diri siswa. Selain itu guru juga mengorganisasikan dan menyiapkan siswa yang terlibat dalam teaching factory. Walaupun hal ini juga terdapat kelemahan, karena tidak semua siswa mempunyai kesempatan untuk terlibat dalam pelaksanaan teaching factory. Sekolah juga melaksanakan evaluasi dan perbaikan hasil pembelajaran teaching factory secara bertahap dan terus menerus, walaupun dalam hal ini tidak semua dilakukan oleh setiap sekolah.

\section{Proses Produksi}

Berdasarkan hasil penelitian, dapat diketahui bahwa kecenderungan guru dalam menilai pelaksanaan teaching factory SMK di Surakarta adalah sebagai berikut, yaitu guru yang menilai bahwa proses produksi berjalan dengan sangat baik berjumlah 12 orang dengan persentase $14,81 \%$, baik berjumlah 22 orang dengan persentase $27,16 \%$, tidak baik berjumlah 36 orang dengan persentase $44,44 \%$, sangat tidak baik berjumlah 11 orang dengan persentase $13,58 \%$.

Hasil kecenderungan tersebut menunjukkan bahwa pelaksanaan teaching factory SMK di Surakarta dari segi kegiatan pembelajaran telah berjalan dengan baik. Pelaksanaan teaching factory dalam hal proses produksi tidak dapat berjalan dengan baik karena indikator yang mempengaruhi keberhasilan proses produksi tidak dapat terlaksana dengan baik. Berdasarkan analisis rerata butir, indikator-indikator yang terlaksana 
dengan tidak baik pada proses produksi yaitu 1) perencanaan, yang meliputi pembuatan program kerja pelaksanaan pengadaan barang, pembuatan rencana kebutuhan barang/bahan dan peralatan penunjang, perencanaan survei barang/bahan, menyediakan barang/bahan yang diperlukan bagi pelaksanaan teaching factory, pemeriksaan bahan atau komponen yang akan dirakit atau pengecekan barang yang akan dijual, pembuatan rekapitulasi bahan baku yang dibeli dari toko pemasok; 2) produksi, yang meliputi adanya design produk sampai produk selesai, menyediakan pelayanan jasa, menyediakan barang kebutuhan konsumen, quality control; 3) penjualan/pemasaran, meliputi melakukan riset pasar, menentukan strategi pemasaran yang sesuai, membuat dan mengembangkan jaringan pasar dan distribusi, melakukan promosi dan pencintraan produk/jasa, mengadakan hubungan/kontrak dengan relasi; 4) purna jual/perbaikan, meliputi pemberian service jika terjadi kerusakan atau ketidak puasan yang dialami oleh konsumen.

\section{Hambatan-hambatan dalam pelaksanaan Teaching Factory SMK di Surakarta}

\section{Kegiatan Pembelajaran}

Berdasarkan hasil penelitian dapat diketahui bahwa hambatan yang ditemui dalam kegiatan pembelajaran pada pelaksanaan teaching factory adalah pada sosialisasi pembelajaran teaching factory dan pada evaluasi serta perbaikan hasil pembelajaran teaching factory.

\section{Proses Produksi}

Berdasarkan hasil penelitian dapat diketahui bahwa hambatan yang ditemui dalam proses produksi pada pelaksanaan teaching factory adalah pada indikator tentang kegiatan penjualan.

\section{Hal-hal yang harus diperbaiki dan ditingkatkan dalam pelaksanaan teaching factory SMK di Surakarta}

\section{Kegiatan Pembelajaran}

Berdasarkan hasil analisa data, dapat diketahui bahwa hal-hal yang perlu diperbaiki pada pelaksanaan teaching factory dalam kegiatan pembelajaran yaitu terletak pada sosialisasi pembelajaran teaching factory dan evaluasi serta perbaikan hasil pembelajaran teaching factory.

Sedangkan hal-hal yang perlu ditingkatkan dalam pelaksanaan teaching factory dari segi kegiatan pembelajaran meliputi hal-hal sebagai berikut, yaitu proses pembelajaran keterampilan lebih disesuaikan lagi dengan standar kerja yang sesungguhnya, setting pembelajaran lebih disesuaikan lagi dengan situasi kerja, pembelajaran lebih diorientasikan pada kegiatan problem solving, pembelajaran lebih diarahkan pada student active learning, pembelajaran lebih ditekankan pada pencapaian kompetensi, pengembangan soft skill lebih ditingkatkan lagi dalam kegiatan pembelajaran, kemauan untuk belajar terusmenerus, pengembangan pola pembelajaran berbasis bisnis, pengorganisasian siswa yang terlibat dalam teaching factory, dan pemberian bimbingan ke siswa pada pelaksanaan kegiatan pembelajaran teaching factory.

\section{Proses Produksi}

Berdasarkan hasil analisa data, dapat diketahui bahwa hal-hal yang perlu diperbaiki pada pelaksanaan teaching factory dalam proses produksi yaitu dalam hal kegiatan penjualan. Hal-hal tersebut meliputi kemampuan riset pasar 
oleh guru dan pengelola teaching factory, penentuan strategi pemasaran oleh guru dan pengelola teaching factory, pembuatan dan pengembangan jaringan pasar serta distribusi produk teaching factory, kegiatan promosi yang dilakukan oleh siswa, dan banyaknya produk (barang/jasa) yang terjual.

Sedangkan hal-hal yang perlu ditingkatkan dalam pelaksanaan teaching factory dari segi proses produksi meliputi hal-hal sebagai berikut, yaitu pada 1) kegiatan perencanaan, yang meliputi pembuatan program kerja pelaksanaan pengadaan barang yang berisi jadwal dan urutan pekerjaan, perancangan kebutuhan barang/bahan dan peralatan yang dibutuhkan sesuai dengan standar kualitas yang berlaku, survei barang/bahan baku yang akan diproduksi atau dipasarkan, pengecekan bahan baku yang akan dirakit/diproduksi dan diperlukan dalam proses penjualan barang/jasa, pengadaan barang/bahan baku yang diperlukan dalam kegiatan teaching factory; 2) kegiatan produksi, yang meliputi design produk yang akan dibuat/dijual, proses perakitan produk oleh siswa, kualitas produk (barang/jasa) yang dihasilkan oleh siswa, sistem pengepakan barang oleh siswa, quality control oleh guru dan karyawan; 3) kegiatan purna jual/perbaikan, yang meliputi layanan keluhan konsumen, dalam hal produk dan jasa, layanan service untuk kerusakan produk, pelayanan yang diberikan kepada konsumen; dan 4) partnership, yang meliputi kerjasama sekolah dengan relasi dari pihak industri atau dunia kerja/usaha, kerjasama dengan pemerintah, kerjasama dengan masyarakat dan pihak sekolah lain.

\section{KESIMPULAN}

Hasil evaluasi pelaksanaan teaching factory SMK di Surakarta menunjukkan bahwa dari segi kegiatan pembelajaran pelaksanaan teaching factory berjalan dengan baik, sedangkan untuk proses produksi berjalan dengan tidak baik. Hambatan-hambatan yang ditemui dan hal-hal yang perlu diperbaiki dalam pelaksanaan teaching factory pada kegiatan pembelajaran adalah dalam sosialisasi pelaksanaan teaching factory dan evaluasi serta perbaikan hasil pembelajaran teaching factory. Sedangkan hambatan dan hal yang perlu diperbaiki dalah proses produksi adalah pada bagian pemasaran.

Hal-hal yang perlu ditingkatkan dalam kegiatan pembelajaran adalah proses pmbelajaran keterampilan lebih disesuaikan dengan standar kerja yang sesungguhnya, setting pembelajaran lebih disesuaikan dengan situasi kerja, pembelajaran lebih diorientasikan pada kegiatan problem solving, pembelajaran lebih diarahkan pada student active learning, pembelajaran lebih ditekankan pada pencapaian kompetensi, pengembangan soft skill dalam kegiatan pembelajaran, kemauan untuk belajar terus menerus, pengembangan pola pembelajaran berbasis bisnis, pengorganisasian siswa yang terlibat dalam teaching factory, dan memberikan bimbingan ke siswa pada pelaksanaan kegiatan pembelajaran teaching factory. Pada proses produksi, hal yang harus ditingkatkan adalah kegiatan perencanaan, produksi, purna jual, dan partnership. 


\section{SARAN}

1. Melakukan sosialisasi tentang pembelajaran teaching factory, baik itu di lingkungan sekolah, orang tua, dan masyarakat sehingga tidak ada perbedaan persepsi dan tujuan dapat dicapai dengan baik serta memperoleh hasil yang maksimal.

2. Pengenalan pentingnya pembelajaran teaching factory di kalangan dunia pendidikan, dunia industri, dan masyarakat secara lebih lagi sehingga pelaksanaan teaching factory di SMK akan mendapatkan banyak dukungan dari berbagai pihak, baik itu dukungan dalam hal materiil maupun spirituil.

3. Melakukan evaluasi dan perbaikan hasil pembelajaran teaching factory, baik itu setiap bulan atau setahun sekali untuk mengetahui hal-hal apa saja yang menjadi penghambat dan apa saja yang perlu untuk diperbaiki, ditingkatkan, dan dibenahi lagi dalam pelaksanaan teaching factory. Sehingga dengan adanya evaluasi dan perbaikan, maka pelaksanaan teaching factory sedikit demi sedikit akan mengalami kemajuan.

4. Meningkatkan kemampuan dalam melakukan riset pasar bagi guru dan pengelola teaching factory.

5. Meningkatkan kemampuan dalam menentukan strategi pemasaran bagi guru dan pengelola teaching factory.

6. Mengembangkan lagi jaringan pasar dan distribusi produk teaching factory.

7. Meningkatakan promosi hasil teaching factory di kalangan masyarakat.

\section{DAFTAR PUSTAKA}

Depdiknas. 2012. Panduan Pelaksanaan, Tahun 2012, tentang Bantuan Pengembangan Kewirausahaan SMK/ teaching industry.

Direktorat Pembinaan SMK. (2011). Data Pokok SMK. Kementerian Pendidikan Nasional, p. (http://datapokok.ditpsmk.net/index.ph p? aksi $=12$ \&page $=3$ )

Dobson, Graeme. (2003). A guide to Writing Competency Based Training Materials. Melbourne: National Volunteer Skills Centre.

E. Mulyasa. (2006). Kurikulum Berbasis Kompetensi - Konsep, Karakteristik, dan Implementasi. Bandung: PT. Remaja Rosdakarya.

Hadlock, H., Wells, S., Hall, J., et al. (2008). From Practice to Entrepreneurship: Rethinking the Learning Factory Approach. Proceedings of The 2008 IAJC-IJME International Conference, ISBN 978-1-60643-379-9.

Herminarto Sofyan. (2008). Optimalisasi Pembelajaran Berbasis Kompetensi pada Pendidikan Kejuruan. Pidato Pengukuhan Guru Besar, disampaikan pada Rapat Terbuka Senat Universitas Negeri Yogyakarta, Sabtu 16 Februari 2008.

Iwan Harianton \& Agus S. Saefudin. (2010). Alternative Approach to deliver Competence Higher Skills Technicians from Diploma Program in Indonesian Higher Educations toward Global Competition. Proceedings of the 1stUPI International Conference on Technical and Vocational Education and Training Bandung, Indonesia, 73-81.

Lamancusa, John S., Jorgensen, Jens E., ZayasCastro, Jose L., et al. (1995). The learning factory - a new approach to integrating design and manufacturing into enginering curricula. ASEE Proceedings, Anaheim, California, 2262.

Lamancusa, John S., Zayas, Jose L., Soyster, Allen L., et al. (2008). The Learning Factory: industry-Partnered Active Learning. Journal of engineering Education. 
Moerwismadhi. (Agustus 2009). Teaching Factory Suatu Pendekatan dalam Pendidikan Vokasi yang Memberikan Pengalaman ke Arah Pengembangan Technopreneurship. Makalah disajikan dalam Seminar Nasional Technopreneurship Learning For Teaching Factory, di Malang Jawa Timur.

Rogers, Glyn, \& Badham, Linda. (2005). Evaluation in Schools: Getting Started on Training and Implementation. New York: Roudledge.

State Board of Education (1997). Production Work Handbook: A Handbook for
Administering Production Work Activities in Workforce Development Education Programs. North Carolina: State Board of Education.

Sudiyanto, G.S., Yoga, S., Ibnu. (2011). Teaching Factory di SMK ST. Mikael Surakarta. Fakultas Teknik Universitas Negeri yogyakarta.

Suharsimi Arikunto \& Safruddin Abdul Jabar. (2009). Evaluasi Program Pendidikan: Pedoman Teoritis Praktis Bagi Mahasiswa dan Praktisi Pendidikan. Jakarta: Bumi Aksara. 